\title{
DINAMIKA PERJUANGAN KAUM MUSLIM DALAM MENCAPAI KEMERDEKAAN INDONESIA
}

\author{
${ }^{1}$ Lalu Murdi, ${ }^{2}$ Muhammad Shulhan Hadi \\ ${ }^{1,2}$ Universitas Hamzanwadi \\ 1alumurdi2014@gmail.com, ${ }^{2}$ muhammadshulhan.hadi@gmail.com
}

\begin{abstract}
This study deals with the dynamics of the struggle of the Muslims to achieve independence both de jure and de facto since the Japanese occupation until after the independence revolution. The method used is historical methods ranging from heuristics, criticism, interpretation and historiography. The documents used range from books, printed and online journal articles. The results of the study show that there are several criteria for the struggle of Muslim believers in Indonesia, namely: first, political struggle. In this case Islamic organizations and Islamic leaders sought to obtain such independence by means of constitutions and organizations that were legalized by the Dutch, such as MIAI which was replaced with Masyumi, social-religious organizations such as Muhammadiyah, NU, Persis and others. Meanwhile in the independence preparation institutions they participated as members of the BPUPKI and formulated the basis for an independent Indonesia. Second, the struggle for state ideology. In this case the Muslims fight for the foundation of the state is Islamic law, and they are not dealing with the Japanese but the national group. The difference between them revolves around the separation of religion from the country which is fought by national groups, whereas Islamic groups fight for Islam as the basis of the state. Third, resistance with rebuke, for example, the Japanese act of implementing the seikere tradition was not only opposed by the NU, but also other Islamic leaders.
\end{abstract}

Keywords: Muslims, Independence, Struggle.

\begin{abstract}
Abstrak
Kajian ini berkaitan dengan dinamika perjuangan kaum muslim untuk mencapai kemerdekaan baik secara de jure maupun de facto sejak masa penjajahan Jepang sampai setelah revolusi kemerdekaan. Metode yang digunakan yaitu metode sejarah mulai dari heuristik, kritik, interpretasi dan historiografi. Adapun dokumen yang digunakan mulai dari buku, artikel jurnal baik yang cetak maupun online. Hasil penelitian menunjukkan bahwa terdapat beberapa kriteria perjuangan kauam muslim di Indonesia yaitu: pertama, perjuangan secara politis. Dalam hal ini organisasi-organisasi islam dan tokoh-tokoh Islam berusaha untuk mendapatkan kemerdekaan tersebutt dengan jalan konstitusi dan organisasi yang di legalkan oleh belanda, seperti MIAI yang diganti dengan Masyumi, organisasi sosial keagamaan seperti muhammadiyah, NU, Persis dan lain sebagainya. Sementara itu dalam lembagapersiapan kemerdekaan mereka ikut sebagai anggota BPUPKI dan merumuskan dasar Negara Indonesia merdeka.Kedua, perjuangan idiologi negara. Dalam hal ini kaum muslim memperjuangkan dasar negara adalah syariat Islam, dan mereka tidak berhadapan dengan pihak Jepang melainkan kelompok nasional. Perbedaan antara mereka berkisar pada adanya pemisahan agama dari negera yang di perjuangkan oleh kelompok nasional, sebaliknya kelompok islam memperjuangkan Islam sebagai dasar negara. Ketiga, perlawanan dengan teguran, misalnya tindakan Jepang memberlakukan tradisi seikere tidak hanya ditentang kalangan NU, tetapi juga tokoh Islam lain.
\end{abstract}

Kata Kunci:Kaum Muslim, Kemerdekaan, Perjuangan. 
Dinamika Perjuangan Kaum Muslim........Lalu Murdi dan Muhammad Shulhan Hadi

\section{Pendahuluan}

Kemerdekaan Indonesia pada tahun 1945 tercipta oleh berbagai faktor dan cita-cita yang berkelindan di dalamnya, dan salah satu cita-cita tersebut tidak lain bertujuan keagamaan (baca: Islam), sehingga di dalamnya terdapat kreasi agama untuk mendapatkan kemerdekaannya, dan salah satu kreator tersebut tidak lain adalah kaum muslim Indonesia.

Kemerdekaan Indonesia 1945 dan yang secara de jure di akui oleh belanda pada bulan Desember 1949, selain di pengaruhi oleh munculnya paham nasionalisme yang menurut Sartono Kartodirjo (1990:ix) bagi dunia ketiga abad ke-20 dapat diberi julukan “Abad Nasionalisme”, yaitu suatu kurun waktu dalam sejarahnya yang menyaksikan pertumbuhan kesadaran berbangsa serta gerakan nasionalis untuk memperjuangkan kemerdekaannya. Sekaligus dorongan agama sebagai motivator sangatlah tinggi. Karena itu Dadang Kahmad (2006) mengatakan setidaknya perang melawan dan menghancurkan kepalsuan dan penjajahan adalah nilai hidup yang lebih tinggi, walaupun di kalangan agama lain juga merasakan seperti itu.

Motivasi agama selain di pengaruhi berkembangnya nasionalisme, seperti yang di katakan Sartono Kartodirjo di atas, di samping itu motivasi agama sangatlah dominan dalam pergerakan kemerdekaan Indonesia. Karena motivasi agama telah mendorong untuk menghancurkan kepalsuan dan penjajahan itu sendiri.

Apabila dianalisis dari perspektif sosiologis, perjuangan kemerdekaan dan perjuangan mempertahankan kemerdekaan yang di lakukan oleh umat Islam di Indonesia dapat di jelaskan sebagai gerakan Umat Islam dalam bentuk pergerakan sosial dan politik. Mengapa di katakan bahwa perjuangan ini sebagai pergerakan sosial dan politik? Pada kenyataannnya perjuangan kemerdekaan Indonesia bukan hanya di lakukan oleh Tentara, kelaskaran yang semi militer lainnya melainkan di lakukan bersama rakyat dalam lapisan yang tidak bisa di identifikasi, sehingga pergerakan tersebut bersifat kolektif. Sejalan dengan itu gerakan sosial menurut Katamso sunarto (2004), dalam bukunya sosiologi menjelaskan pengertian gerakan sosial sebagai perilaku kolektif yang memiliki tujuan jangka panjang untuk mengubah atau mempertahankan masyarakat atau institusi yang ada di dalamnya. (Damsar, 2010: 130). 
Memahami pengertian di atas dengan sendirinya pergerakan memperjuangkan dan mempertahankan kemerdekaan di Indonesia oleh umat Islam yang dilakukan secara kolektif bertujuan untuk mengubah atau juga mempertahankan masyarakatnya. Yang mereka harus rubah adalah kemiskinan, kebodohan, penjajahan, penderitaan, penistaan agama dan lain sebagainya yang di lakukan oleh penjajah, dan yang harus mereka pertahankan adalah rasa aman, kebahagiaan, kemerdekaan dan lain sebagainya seperti yang selayaknya dan hal itu termaktub dalam ajaran agama Islam sendiri.

Dalam hal ini Herry J. Benda menyatakan bahwa sejarah Islam Indonesia adalah sejarah perluasan peradaban santri dan pengaruhnya terhadap kehidupan agama, sosial, dan politik di Indonesia (Ajid Tohir, 2009: 303-304).Oleh karena itu tidak salah jika setelah kemerdekaan sebagaimana yang dianjurkan oleh Badan Pekerja Komite nasional Pusat (BPKNP) 27 Desember 1945 menyebut bahwa: "Madrasah dan pesantren yang pada hakikatnya adalah satu alat dan pencerdasan rakyat jelata yang sudah berurat berakar dalam masyarakat Indonesia pada umumnya, hendaklah pula mendapat perhatian dan bantuan nyata dan bantuan material dari pemerintah" (Samsul Nizar, 2011: 345).

Karena pesantren selain menghasilkan tokoh-tokoh pejuang, namun juga mampu menarik masa yang sangat banyak untuk membantu perjuangan kemerdekaan Indonesia, hal ini terbukti dari bagaimana perlawanan rakyat pada umunya dan hizbullah serta sabilillah sebagai organisasi semi militer pada hususnya. Kemampuan pesantren menarik masa pejuang tidak lain adalah karena karisma dari pemimpin-pemimpin pesantren yang di kenal dengan Kiai.

Selain itu, supaya kita terbebas dari klasifikasi yang keliru dalam menamakan pergerakan umat Islam, sebab apa yang kita sebut saat ini sebagai tokoh nasionalis moderat ternyata sangat taat beragama. Dan jika kita tinjau dari hal ini jelas semua mereka beragama islam dan sangat sedikit sekali tokoh-tokoh yang beragama di luar islam. Jadi, yang menjadi persoalan dan perlu kita klasifikasi adalah idiologi yang di usung oleh partai, dan tokoh-tokoh yang ada. sehingga dengan sendirinya menjadi jelas perjuangan umat islam mana yang di maksudkan, yaitu sekali lagi tergantung idiologi yang di usungnya. 


\section{Metode}

Metode penelitian yang digunakan dalam kajian ini adalah metode kepustakaan yang menekankan pada sumber dokumen. Adapun dokumen yang digunakan dalam hal ini berupa buku, artiker jurnal baik yang cetak maupun online. Struktur penulisan dalam kajian ini mengikuti langkah-langkah dalam metode sejarah mulai dari heuristik, kritik, interpretasi data, dan historiografi meskipun tidak begitu ketat.

\section{Pembahasan}

\section{A. Corak Perjuangan Kemerdekaan Umat Islam Pada Masa Pendudukan Jepang}

Terdapat perbedaan penting bagaimana para tokoh nasional dalam menanggapi dan bersikap pada masa penjajahan Belanda dengan sikap mereka pada saat penjajahan Jepang, bila mana, pada masa sebelumnya mereka terkenal dengan nonkooperasinya, justru pada masa Jepang mereka justru berbalik arah dengan cara kerjasama (kooperasi), padahal sebelumnya mereka dikenal sebagai anti Fasis. Begitu juga halnya dengan perjuangan kaum nasionalis Islam untuk mendapatkan kemerdekaan, karena janji-janji Jepang dan kelihatannya Jepang lebih menjanjika Indonesia untuk dapat merdeka maka gologan Islam menerima kerjasama sebagai jalan untuk memperjuangkan kemerdekaannya di kemudian hari, walaupun tidak terhindarkan juga walaupun terdapat kerjasama, namun karena sikap Dai' Nippon maka tidak sedikit perlawanan yang dilancarkan.

Pada awal pendudukan Jepang di Indonesia Islam memiliki posisi yang lebih dominan dibandingkan dengan kelompok nasionalis, tapi pada akhirnya, sejalan dengan makin mengendurnya upaya-upaya strategis Jepang untuk memenangkan perang (dan kerenanya membuka lebih lebar pintu menuju kemerdekaan), pemerintah kolonial Jepang mengubah arah kebijakan mereka. Sejalan dengan itu, beberapa badan komite negara yang penting, yang dibentuk untuk mempersiapkan kemerdekaan Indonesia diserahkan kepada para pemimpin nasionalis, seperti BPUPKI dan PPKI (Bahtiar Effendi, 1998: 84). Hal ini menyebabkan fungsi strategis tokoh-tokoh Islam dalam badan persiapan kemerdekaan Indonesia dalam BPUPKI dan PPKI yang hanya sebagai anggota tidak terlalu mudah untuk memperjuangkan keinginan mereka menjadikan 
Indonesia dalam Undang-Undang yang berlandaskan syariat Islam seperti yang di citacitakan dalam idiologi yang di perjuangkannya.

Penting juga di perhatikan bahwa, meskipun pada masa ini tokoh nasional islam dan lainnya berjuang dengan cara kerja sama, tidak mesti di artikan sebuah kepatuhan. Berdasarkan hal itu, beberapa corak perjuangan umat Islam pada masa pendudukan Jepang dapat di klasifikasikan sebagai berikut:

\section{Kerjasama secara Politis}

Dalam rangka melukiskan kehidupan politik pada jaman pendudukan Jepang, dimana golongan nasionalis Islam memperoleh sorotan khusus karena telah memperoleh perhatian istimewa dari pemerintah pendudukan Jepang. Golongan ini memperoleh lebih banyak kelonggaran dibandingkan dengan golongan nasionalis "sekuler" karena dinilai pada dasarnya anti Baratkarena soal agama karenanya lebih dapat diandalkan oleh Jepang. Dalam rangka memberikan kelonggaran kepada golongan Islam di pulau Jawa misalnya, pemerintah militer masih mengijinkan tetap berdirinya suatu organisasi Islam dari jaman Hindia Belanda yaitu Majelis Islam A'la Indonesia (MIAI) yang didirikan di Surabaya pada tahun 1937 oleh K.H. Mas Mansur dan kawankawan.

Satu hal yang memberi dorongan tokoh nasionalis Islam untuk bekerjasama dengan pihak jepang adalah faktor kondisional yang dikembangkan oleh pemerintah Jepang. Sehingga perjuangan bukan saja harus melalui perlawanan bersenjata melainkan juga politik dan perjuangan kemerdekaan inilah yang dirasakan cukup intensip pada masa pendudukan Jepang. Karena itu sampai pada di rumuskannnya Piagam Jakarta dan perumusan UUD Negara Republik Indonesia tidak lepas dari perjuangan tokoh-tokoh Islam dalam memperjuangkan kemerdekaannya secara politis. Atau secara tidak langsung juga dapat kita katakana bahwa pada saat ini terjadi politisi Kyai.

Pada masa pendudukan Jepang, bagi kelompok-kelompok Islam, masa singkat itu member kesempatan yang jauh lebih besar untuk memperkuat basis sosial-politik mereka, hal ini terbukti dari beberapa konsesi yang diberikan kepada mereka. Beberapa konsesi yang diberikan misalnya mencakup (1) pembentukan kantor urusan agama (shumubu); (2) pembentukan Majlis Syura Muslimin Indonesia (Masyumi); dan (3) 
pembentukan Hizbullah, organisasi militer untuk para pemuda muslim. Karena itu Abikusno Tjokrosujoso (Bahtiar Effendi, 1998), mengatakan bahwa:

Kebijakan pemerintah Belanda telah memperlemah posisi Islam. Islam tidak memiliki para pegawai di bidang agama yang terlatih di masjid-masjid atau pengadilan-pengadilan Islam. Belanda menjalankan kebijakan yang memperlemah posisi Islam. Ketika pasukan Jepang datang, mereka menyadari bahwa Islam adalah suatu kekuatan di Indonesia yang dapat dimanfaatkan (Bahtiar Effendi, 1998: 82-83).

Mula-mula Jepang memilih MIAI sebagai wadah daripada golongan Islam sebagai satu-satunya organisasi gabungan, yang dimiliki umat Islam. Tetapi MIAI maru diakui pemerintah militer Jepang sesudah mengubah anggaran dasar (azas dan tujuannya). Pada azas dan tujuan MIAI ditambahkan kalimat "turut bekerja dengan sekuat tenaganya dalam pekerjaan membangunkan masyarakat baru, untuk mencapai kemekmuran bersama di lingkungan Asia Raya di bawah pimpinan Dai Nippon". Kegiatan MIAI yang sangat menonjol ialah membentuk baitul mal yang berkembang pesat di daerah-daerah. Kolonel Horie sebagai pejabat yang menangani masalahmasalah keagamaan berusaha terus untuk menggarap kyahi yang berada di daerah Jawa Barat. Pada bulan Januari 1943 secara berturut-turut Horie mengadakan pertemuan di beberapa kota kabupaten. Ia mengarahkan para pembantunya orang Jepang Islam seperti Abdul Muniam Inada serta Moh. Sayido Wakas, agar secara bergilir mengunjungi beberapa masjid besar yang ada di Jakarta, untuk mengadakan ceramah dan khotbah jum'at (Poesponegoro \& Notosusanto, 1993: 24-25).

Pada bulan September 1943, dua organisasi Islam yakni Nahdlatul Ulama dan Muhammadiyah diijinkan berdiri kembali untuk melakukan kegiatan-kegiatan di bidang kerohanian dan sosial. MIAI bagi Jepang ternyata masih kurang memuaskan karena menurut seleranya kegiatannya terbatas. Pada bulan Oktober 1943, secara resmi MIAI dibubarkan dan diganti dengan organisasi baru yang bernama Majelis Sjoero Moeslim Indonesia (Masjoemi) yang disahkan Gunseikan pada 22 November 1943 dengan pimpinan Ketua Pengurus Besar K.H. Hasyim Asy’ari, dengan wakil dari Muhammadiyah K.H. Mas Masnsur, K.H. Farid Ma'ruf, K.H. Mukti, K.H. Hasjim, Kartosudarmo dan dari NU, K.H. Nachrowi, Zainal Arifin, K.H. Mochtar (Poesponegoro \& Notosusanto, 1993: 26). Selain itu, pemerintah Jepang akan membubarkan organisasi sosial, politik, keagamaan yang tidak mau diajak kerjasama, 
Dinamika Perjuangan Kaum Muslim........Lalu Murdi dan Muhammad Shulhan Hadi

sebaliknya yang masih mau diajak kerjasama akan dikooptasi. Hanya NU dan Muhammadiyah yang diperbolehkan secara sah oleh Jepang untuk menjadi anggota Masyumi.

Pada tahun 1944, NU pertama kalinya masuk ke dalam struktur pemerintahan dengan diangkatnya K.H. Hasyim Asy’ari sebagai ketua Shummubu (Kantor Urusan Agama). Pada tahun itu juga K.H. Wahid Hasyim berhasil melobi Jepang untuk memberikan pelatihan militer khusus kepada para santri dan mengizinkan mereka membentuk barisan pertahanan rakyat tersendiri yakni Hizbullah dan Sabilillah. Sejak saat itu ormas Islam memiliki pasukan tersendiri, sedangkan kaum nasionalis yang netral agama menguasai tentara nasional (peta) yang dibentuk Jepang.

Baik Peta, Hizbullah ataupun Sabilillah yang diharapkan Jepang bisa membantu perang Asia Timur Raya, yang terjadi malah sebaliknya, kemampuan mereka inilah yang dipergunakan untuk memukul Jepang. Pada tanggal 7 September 1944, Perdana Jepang Kuaki Kaiso menjanjikan kemerdekaan kepada Indonesia di kemudian hari. Janji itu dilontarkan karena di beberapa medan pertempuran, Jepang mengalami kekalahan terhadap Sekutu. Janji itu kemudian di respons secara positif oleh Pimpinan Kongres Umat Islam se-Dunia, Syekh Muhammad Amin Al-Husaini dari Palestina mengirimkan surat kepada pemerintah Jepang melalui Duta Besar berkuasa penuh pemerintah Jepang untuk Jerman. Surat itu juga ditembuskan kepada K.H. Hasyim Asy'ari (Rais Am Masyumi). Dengan cepat beliau menyelenggarakan rapat khusus Masyumi pada tanggal 12 Oktober 1944, yang menghasilkan resolusi ditujukan kepada pemerintah Jepang.

Resolusi tersebut berisi; pertama, mempersiapkan Umat Islam Indonesia agar mampu dan siap menerima Kmerdekaan Indonesia dan agama Islam. Kedua, mengaktifkan kekuatan umat Islam Indonesia untuk memastikan terlaksananya kemenangan final dan mengatasi setiap rintangan dan serangan musuh yang mungkin berusaha menghalangi kemajuan kemerdekaan Islam dan Agama Islam. Ketiga, bertempur dengan kekuatan tenaga bersama Jepang Raya di jalan Allah untuk mengalahkan musuh. Keempat, menyebarkan resolusi ini kepada seluruh tentara Jepang dan kepada segenap bangsa Indonesia. 
Di samping itu, selain NU dan Muhammadiyah terdapat juga Persis, Al-Irsyad dan lain-lain. Upaya mempopulerkan nama Persis dilakukan oleh para kadernya yang banyak menjadi orang berpengaruh dalam percaturan politik nasional. Nama seperti Muhammad Natsir, dia adalah figur yang benyak berbicara tentang konsep nasionalisme muslim di Indonesia, selain itu Haji Abdul Karim Amrullah (HAMKA) Persis merupakan organisasi perjuangan yang memiliki tujuan mulai; menciptakan masyarakat yang berlandaskan ajaran serta hokum Islam (Mukhsin Jamil dkk. 2007:186).

Dalam keanggotaan Masyumi, Persis merupakan anggota istimewa di samping Nahdlatul Ulama Muhammadiah. Dalam berpolitik, persis menggunakan otoritas lembaganya guna menginstruksikan pada seluruh warganya untuk masuk dalam partai masyumi. Prinsip politik Persis adalah: semua orang Islam hendaklah berpolitik, sebab politik merupakan salah satu kewajiban agama (islam) untuk berjuang demi kemaslahatan umat. Pada tahun 1945 Natsir masih sebagai anggota Masyumi, dan sebagai ketua mulai 1949-1956 (Mukhsin Jamil dkk, 2007: 206).

Dari uraian di atas dapat di katakana bahwa Masyumi merupakan basis politis dari organisasi-organisasi Islam seperti Nahdlatul Ulama, Muhammadiyah, Persis dan lain sebagainya, sehingga keterlibatan mereka dalam persiapan kemerdekaan Indonesia sangatlah vital. Karena Masyumi merupakan satu-satunya kendaraan politik bagi umat Islam maka beberapa tokoh dari beberapa organisasi bersar ada di dalamnya dan memberikan sumbangan yang sangat besar guna kemerdekaan bangsa Indonesia ini.

Salah satu perjuangan yang di tempuh oleh umat Islam melalui kendaraan politik adalah keterlibatan tokoh-tokoh organisasi Islam dalam perumusan dasar negara dan UUD 45. Perumusan itu sendiri merupakan realisasi dari peristiwa pada tanggal 7 September 1944 di dalam siding istimewa ke-85 Teikoku Ginkai (parlemen Jepang) di Tokyo, Perdana Mentri Kaiso mengumumkan tentang pendirian pemerintah kemaharajaan Jepang, bahwa daerah Hindia Timur (Indonesia) diperkenankan merdeka "kelak dikemudian hari". Apa yang sebenarnya menyebabkan dikeluarkannya pernyataan tersebut adalah karena semakin terjepitnya angkatan perang Jepang. Dalam bulan Juli 1944. Kepulauan Saipan yang letaknya sudah sangat dekat dengan kepulauan Jepang jatuh ke tangan Amerika, yang menimbulkan kegoncangan dalam masyarakat Jepang. Karena itu Jendral Kumakici Harada pada tanggal 1 Maret 1945 telah 
mengumumkan pembentukan Badan Penyelidik Usaha-Usaha Persiapan Kemerdekaan (Dokuritsu Junbi Cosakai) yang di ketuai oleh dr. K.R.T. Radjiman Wediodiningrat, dan R.P. Suroso sebagai sekertaris dengan dibantu oleh Toyohito Masuda dan Mr. A.G. Pringgodigdo (Poespoenegoro \& Notosusanto, 1993: 66-67). Pembentukan BPUPKI ini juga selain didasari faktor di atas, Tokoh terkemuka NU, KH. Wahid Hadsyim tidak henti-hentinya mengadakan kontak dengan para tokoh nasionalis untuk mendesak pemerintah militer Jepang agar segera mewujudkan janji kemerdekaan yang pernah diucapkan. Perjuangannya berhasil dengan gemilang.

Selain itu, keterlibatan tokoh-tokoh Islam dalam merancang dasar negara secara kolektif (dalam istilahnya Anhar Gonggong) yang di kenal dengan Panitia Sembilan atau panitia kecil, nama-nama seperti Wahid Hasjim, H. Agus Salim, dan Abdulkadir Muzakir merupakan perwakilan dari kaum muslim. Bersama tokoh nasional lainnya seperti Ir. Sukarno, Drs. Moh. Hatta, Mr. Muh. Yamin, Mr. Ahmad Subardjo, Mr. A.A. Maramis, dan Abikusno Tjokrosujoso, mereka inilah yang menghasilkan Piagam Jakarta yang oleh Muh. Yamin diberi namaJakarta Charter sebagai rumusan awal dari Pancasila. Namun yang membedakannya dari pancasila yang sekarang dengan rumusan Piagam Jakarta adalah pada alinea pertama yang berbunyi "Ke-Tuhanan, dengan kewajiban menjalankan Syariat Islam bagi pemeluk-pemeluknya". Begitu juga perancang Undang-Undang Dasar dan perumus Undang-Undang dasar terdapat nama Agus Salim dan Wachid Hasyim.

Satu hal yang perlu di pertanyakan juga dari perjuangan tokoh nasionalis yang secara luas mendukung dan bekerjasama dengan pihak penjajah. Namun dari beberapa analisa, ada beberapa alasan mereka lebih memilih jelan koopertaif ini pada masa pendidikan Jepang jika di bandingkan dengan masa penjajahan Belanda. Beberapa alasan tersebut adalah:

a. Tokoh nasional agamais dan nasional pada umumnya mempunyai keyakinan bahwa Jepang dengan gerakan Pan-Asianya mendukung pergerakan Indonesia. Hal ini sebelum terjadi perang dunia II sikap Jepang sudah di jejaki oleh Muhammad Hatta, dan keyakinan inilah yang diinformasikan pada tokoh-tokoh yang lain, termasuk di dalamnya adalah tokoh-tokoh yang bergerak dengan idiologi keislaman 
b. Jepang mendukung suatu pemerintahan sendiri, seperti yang di tegaskan di adlam propagandanya sebelum ia melakukan penyerbuan ke wilayah Indonesia.

c. Posisi Indonesia pada saat itu sangat lemah. Kerena itu dengan adanya propaganda dan janji Jepang seperti di atas tokoh islam dan nasional lainnya mau melakukan kerjasama, karena itu bantuan Jepang diperlukan oleh rakyat Indonesia untuk mencapai cita-citanya.

d. Bercermin dari penguasa sebelumnya yaitu adanya sikap keras kepala pemerintah Hindia Belanda, menjelang akhir kekuasaannya, misalnya dengan menolak Petisi Sutardjo, menolak usulan GAPI dengan usulan "Indonesia Berparlemen" dan lain sebagainya. Kerena itu muncul keyakinan bahwa dari pihak kolonial Belanda tidak di harapkan apa-apa yang menyangkut kemerdekaan, sedangkan pihak Jepang sejak semula berbicara mengenai kemerdekaan bangsa-bangsa Asia.

e. Pemerintah Jepang mengatakan bahwa tujuannya bukan untuk menjajah Indonesia, melainkan untuk membebaskan sekalian bangsa Asia dari dominasi negara Barat.

\section{Perjuangan Idiologi Negara}

Terkait dengan idiologi sebagai dasar negara, tokoh pemikir yang biasanya dikutif dan dijadikan sandaran argument adalah Ernest Renan. Renan mengemukakan bahwa sebuah bangsa dapat berbentuk idiologi kebangsaannya karena asas rohani yang timbul dari keadaan historis yang tersusun secara mendalam. Bagi renan keinginan untuk hidup bersama adalah suatu hal yang penting dan kebangsaan itu merupakan suatu ikatan solidaritas yang membentuk korban dan bersedia untuk memberikan korban lebih banyak. Apa yang dikemukakan oleh Renan tersebut pada dasarnya adalah sifat dari sebuah idiologi apapun. Merujuk dari fungsi idiologi, maka suatu hal yang pasti adalah adanya suatu cara pandang dalam memandang dunia secara ideal dan sekaligus menuntut adanya pengorbanan dari mereka yang meyakininya manakala idiologi tersebut ingin diwujudkan secara nyata (Adhyaksa Dault, 2005: 54). Karena itu pentingnya idiologi sebagai pembentuk kesatuan masyarakat sangatlah urgen sifatnya.

Oleh karenanya, Selain berjuang untuk mendapatkan kemeredekaan secara politis seperti di terangkan di atas, perjuangan untuk menjadikan Negara Islam Indonesia 
adalah salah satu perjuangan Islam yang terus di kumandangkan baik sejak pramedeka maupun setelahnya. Perjuangan idiologi ini sebenarnya bukan dengan penjajah, namun dengan kaum nasionalis, walaupun demikian, penunjukan tokoh nasional skuler sebagai ketua dari badan-badan yang sangat penting untuk mempersiapkan kemerdekaan seperti BPUPKI dan PPKI merupakan suatu tantangan juga. Jadi yang di perjuangkan pada saat sebelum kemerdekaan oleh kelompok islam adalah idiologi Negara yang berlandaskan keislaman. Dan inilah pertentangan perjuangan idiologi oleh tokoh islam dengan nasional skuler lainnya.

Gagasan utama dari kaum nasional moderat (sekuler), misalnya Sukarno mengenai masalah ini sangat erat dengan gagasan pemisahan agama dari negara dan pemerintahan, sebab agama merupakan aturan-aturan spiritual (akhirat) dan negara adalah masalah duniawi (Suhelmi Ahmad, 2002: 80). Kerena itu dalam upaya membangun negara modern, Soekarno menemukan obat penawar bagi kemunduran Islam (karena beliau menganggap jika Islam dijadikan hukum negara maka akan ada kemunduran agama Islam), ia yakin sepenuhnya bahwa penyatuan Islam dan negara hanya akan mengakibatkan kemandegan Islam (Bahtiar Effendi. 1998: 78). Sementara dari kalangan Islam mengatakan bahwa Islam adalah agama yang holistik yang tidak bisa di pisahkan dari negara.

Perdebatan-perdebatan dalam pertemuan-pertemuan Badan Penyelidik Usaha Persiapan Kemerdekaan Indonesia (BPUPKI), bisa dikatakan terlibat dalam perdebatan resmi dengan rekan-rekannya dari kelompok Islam dan nasional moderat untuk menemukan kompromi mengenai rumusan idiologis dan pertauran konstitusional Indonesia merdeka.

Dalam berbegai pertemuan di badan BPUPKI, sejauh mengenai corak hubungan antara Islam dan negara, tampak jelas bahwa mereka mengikuti model penalaran yang sama. Kelompok Islam yang saat itu dipelopori Ki Bagus Hadikusumo, Abdul Kahar Muzakkir, Abikusno Tjokrosujoso, dan A. Wahid Hasjim, pada intinya berpandangan bahwa, karena posisi Islam begitu mengakar, maka negara harus didasarkan kepada Islam. Di pihak lain berdiri kelompok nasionalis, yang dipelopori Soekerno, Hatta dan Supomo, yang membela pandangan bahwa, untuk mempersatukan kesatuan bangsa, 
maka watak Negara harus di-dekonfessionalisasi (meskipun sama sekali tidak berarti tidak religious) (Bahtiar Effendi, 1998: 85).

Perbedaan pandangan antara golongan Islam dan golongan moderat dalam musyawarah ini, hususnya kalangan moderat tidak lepas dari pengaruh bagaimama keterlibatan Islam dalam pandangan para elit Turki (Kamal Ataturk, Halide Edib Honoum, Mahmud Esad Bey) yang diikuti Sukarno dan kawan-kawannya beranggapan bahwa, keterlibatan Islam dalam proses politik negara hanya akan menghadapkan agama itu kepada persoalan-persoalan yang tidak ringan. Jika menjadi bagian dari politik negara, maka Islam berada pada posisi politik yang rentan untuk dijadikan alat pembenaran bagi kepentingan-kepentingan duniawi. Di tangan seorang diktator, Islam akan menjadi alat bagi penindasan politik. Karena itu, jalan terbaik untuk menjaga kepentingan Islam adalah dengan memisahkan dari negara, dan membiarkannya ada di tangan pemeluknya. Dalam konteks ini, dalam pandangan Sukarno dimaksudkan untuk membebaskan Islam dari penyalahgunaan secara kelembagaan oleh negara (Bahtiar Effendi, 1998: 79).

Bertolak belakang dengan posisi Sukarno dan kelompok nasional moderat lainnya, kelompok Islam yang di wakili oleh Natsir menjadi pembela utama paham penyatuan agama dan negara. Seperti banyak umat Islam lain, Natsir percaya akan watak holistik Islam. Ia amat mendukung pernyataan H.A.R. Gibb, yang memang mendapat sambutan luas di kalangan umat Islam, bahwa "Islam itu sesungguhnya lebih dari suatu sistem agama saja, dia adalah suatu kebudayaan yang lengkap. Bagi Natsir, Islam tidak hanya terdiri dari praktik-praktik ibadah, melainkan juga prinsip-prinsip umum yang relevan untuk mengatur hubungan antar individu dan masyarakat (Bahtiar Effendi, 1998: 85)

Karena itu, bagi Natsir, agama (baca: Islam) tidak dapat dipisahkan dari negara, ia menganggap bahwa urusan kenegaraan pada pokoknya merupakan bagian integral risalah Islam. Menurut Natsir, kesalah pahaman terhadap Negara Islam, negara yang menyatukan agama dan politik, pada dasarnya bersumber dari kekeliruan memahami gambaran pemerintah Islam (Ahmad Suhelmi, 2002: 87).

Karena kondisi Negara, untuk menjembatani berbegai perbedaan diantara kelompok Islam dan kelompok nasionalis, bermuara pada pembentukan panitia kecil 
yang di dalamnya terdapat komposisi antara kelompok agama (Islam) dan kelompok nasionalis moderat. Hasil kesepakatan dari panitia kecil inilah yang kita kenal dengan sebutan Piagam Jakarta. Pada dasarnya perumusan Piagam Jakarta (Jakarta Charter) ini telah memberikan kemenangan bagi kelompok nasionalis islam. Karena salah satu alineannya menunjukkan adanya kewajiban untuk memberlakukan syariat Islam bagi pemeluk-pemeluknya. Namun, entah kerena alasan politik, atau menjaga kesatuan dan persatuan dari pendudukan Indonesia yang multi agama mengharuskan penghapusan alinea ini.

\section{Perjuangan dengan Pengecaman}

Tidak diragukan lagi, dalam upaya nasionalistik ini, Islam memainkan peranan yang sangat menentukan. Seperti di catat oleh para pengkaji nasionalisme Indonesia, Islam berfungsi sebagai mata rantai yang menentukan rasa persatuan nasional menentang kolonialisme belanda dan Jepang. Karenany, "Agama Muhammad”, tulis George Mc Turnan Kahin dalam karyanya yang kelasik, Nationalisme and Revolution in Indonesia, " bukan saja merupakan mata rantai yang mengikat tali persaudaraan ; melainka ia merupakan simbol kebersamaan nasib (ingroup), menentang penjajah asing dan penindasan yang berasal dari agama lain (Bahtiar Effendi, 1998: 62-63). Inlah salah satu kekuatan islam dalam menentang penjajahan baik secara politik, idiologis, maupun dengan cara perjuangan bersenjata ini.

Pada masa kolonial Belanda masih bercokol, hususnya dari kalangan pesantren yang memang pada sarnya menunjukkan sikap nonkooperatif radikal, beberapa perlawanan bersenjata menjadi corak perjuangan. Seperti dikemukakan Karel Steenbrink, adalah perlawanan Kiai Mojo di Tegalrejo Magelang, Kiai Rifa'ie di Kalisasak Batang, pemberontakan Kiai Haji Zainal Mustafa di Sukamah Tasikmalaya, Kiai Hasyim Asy'ary di Tebuireng Jombang, dan sebagainya (Amin Haedari, 2004: 11).

Setelah Belanda "bubar" dan diganti penjajah baru Dai Nippon (Jepang) pada Maret 1942, NU mengalami masa ujian yang amat pelik. Pada masa ini banyak tokoh NU yang dijebloskan ke penjara, seperti yang dialami KH. Hasyim Asy'ari dan KH. Mahfudh Shiddiq karena dituduh menggalang kekuatan massa untuk melawan "Saudara Tua”. Kecerobohan Jepang (memenjara para pemimpin NU) membuat warga NU yang semula simpati berbalik menjadi antipasti. Karena itu, mereka membentuk lascar-laskar 
jihad yang di beri nama Hizzbullah dan Sabilillah, dan dipimpin langsung oleh para tokoh NU, seperti KH. Wahib Wahab, KH. Saefuddin Zuhri, KH. Masjkur, dll. Adapun tindakan Jepang memberlakukan tradisi seikere tidak hanya ditentang kalangan NU, tetapi juga tokoh Islam lain. Abdul Karim Amrullah, juga menentang tradisi itu (Mukhsin Jamil dkk. 2007: 299).

Namun dari catatan sejarah bila perjuangan dimaknai sebagai mengangkat senjata bisa dilacak lewat perlawanan KH. Zainal Mustafa dari Pesantran Sukamah (ketua PCNU Tasikmalaya pada tahun 1944. Perlawanan inilah yang sebenarnya sebagai prolog dari perlawanan di daerah lain seperti Cirebon, Cianjur, hingga Blitar atau yang dikenal dengan pemberontakan Supriayadi Belitar. Juga peran KH. Abbas di Cirebon dalam melawan Jepang.

Pada umumnya, dari penjelasan di atas, walaupun di akhir-akhir pendudukan jepang terdapat perlawanan bersenjata, pada awal-awalnya mereka lebih condong melawan dengan cara teguran atau pernyataan ketidak sukaan atas peraturan yang di terapkan, misalnya dalam kasus upacara sikerei tadi yang tidak sesuai dengan syariat Islam, kerena harus menyembah mata hari yang terbit di sebelah timur dengan berjongkok yang dalam Islam di sebut ruku' di katakan sebagai penghinaan terhadap agama Islam yang hanya menyembah satu tuhan yang tunggal yaitu Allah SWT, bukannya matahari seperti yang di lakukan oleh Jepang. Karena itu banyak tokoh-tokoh Islam mengecam keherusan tersebut, namun tidak sampai terjadi perlawanan bersenjata.

\section{B. Corak Perjuangan Umat Islam Setelah Kemerdekaan dan Masa Revolusi}

Setelah proklamasi kemerdekaan Indonesia ternyata perjuangan masih terus berlanjut. Kondisi kehidupan berbangsa dan bernegara diliputi ketegangan setelah kekalahan Jepang dari Sekutu. Sekutu yang datang ke Indonesia untuk melakukan pelucutan senjata terhadap Jepang dilihat sebagai musuh yang akan mengembalikan Indonesia ke tangan Belanda kembali.

Para Kiyai dan pengikutnya dalam jumlah yang sangat besar sejak awal terlibat aktif dalam perang kemerdekaan. Banyak dari mereka yang tergabung dalam barisan Hizbullah yakni kelompok semi-reguler yang dilatih kemiliteran oleh tentara Jepang sebagai pejuang mempertahankan kemerdekaan Indonesia yang sudah di proklamirkan 
pada bulan Agustus 1945. Sekaligus juga tidak ketinggalan bahwa perjuangan kaum muslim Indonesia yang diwakili oleh tokoh-tokohnya dengan jalan politik perdamaian dan diplomasi dengan pemerintahan Belanda. Karena itu untuk dapat mempermudah pemahaman kita bagaimana corak perjuangan umat Islam di Indonesia dalam mempertahankan kemerdekaan dapat diidentifikasi:

\section{a. Pejuangan dengan Senjata}

Setelah Indonesia merdeka, pada tanggal 23 Agustus Presiden Sukarno dalam pidato radionya menyatakan berdirinya tiga badan baru yaitu: Komite Nasional Indonesia (KNI), Partai Nasional Indonesia (PNI) dan Badan Keamanan Rakyat (BKR). BKR ini akan bertugas sebagai penjaga keamanan umum di daerah-daerah di bawah koordinasi KNI daerah. BKR inilah sebagai senjata awal dari perjuangan dalam mempertahankan kemerdekaan dari NICA atau Belanda.

Salah satu contoh, pada tanggal 25 Oktober 1945, Brigade 49 di bawah pimpinan Jendral A.W.S. Mallaby mendarat di Surabaya. Brigade ini adalah bagian dari Divisi India ke-23 di bawah pimpinan Jendral D.C. Hawthorn. Mereka mendapat tugas dari panglima AFNEI untuk melucuti serdadu Jepang dan menyelamatkan para interniran Serikat. Kedatangan mereka diterima secara enggan oleh pemerintah Jawa Timur, yang dipimpin oleh Gubernur R.M.T.A. Suryo yang menghasilkan perjanjian damai. Namun, perkembangan kemudian ternyata pihak Inggris mengingkari janjinya. Mereka membonceng pemerintahan Belanda yaitu Netherlands Indies Civil Administration (NICA). Kondisi dan kenyataan ini membuat para pemimpin Indonesia sangat marah, termasuk para Ulama.

Karena itu, ketika tentara sekutu (NICA) mencoba menggantikan kedudukan Jepang, NU segera mengambil para konsulnya se-Jawa dan Madura guna menentukan sikap terhadap NICA. Pertemuan para konsul dilaksanakan di markas besar NU, di Bubutan Surabaya pada tanggal 21-22 Oktober 1945. Rapat dipimpin langsung oleh Rais Akbar KH. Hasyim Asy'ari, dan berhasil mengeluarkan sebuah "Resolusi Jihad" yang mewajibkan kepada seluruh warga NU untuk berperang melawan penjajah guna mempertahankan kemerdekaan. Seruan ini begitu menggema ke seluruh jaringan NU, sehingga mereka segera bergabung dalam laskar Hizbullah dan Sabilillah di setiap pondok pesantren untuk berlatih perang dan ilmu kebal (semacam ilmu kanuragan/ 
beladiri yang membuat seorang tahan dari senjata atau benda tajam) (Mukhsin Jamil dkk. 2007:299). Isi resolusi Jihad itu adalah “berperang menolak dan melawan penjajah itu fardu ain (bagi yang berada dalam jarak lingkaran $94 \mathrm{~km}$ dari tempat musuh dan kedudukan musuh). Bagi orang-orang yang berada di luar jarak lingkaran tadi, kewajiban itu menjadi fardu kifayah.

Resolusi ini disampaikan kepada Presiden dengan perantara delegasi Mu'tamar; Panglima Tinggi TRI; Hizbullah; Sabilillah dan Ra'yaat Resolusi Jihad sangat berpengaruh besar terhadap umat Islam. Banyak dari para pemuda NU, Muhammadiayah dan masyarakat umum yang kemudian bergabung ke pasukanpasukan non regular seperti Hizbullah dan Sabilillah, mereka inilah yang berjuang dalam perjuangan yang dikenal sebagai perang 10 November 1945.

Perjuangan bersenjata yang bermuara pada pertempuran Surabaya, Ambarawa, Medan Area, dan lain-lain tidak lepas dari perjuangan umat Ini. Tidak lepas dari semua itu, resolusi jihad dan kritiknya terhadap pemerintah RI yang dianggap pasif menghadapi serangan kaum aggressor penjajah, NU, Muhammadiah dan lainnya telah menampilkan dirinya sebagai kelompok yang cinta tanah air dengan membangun kekuatan radikal melawan musuh dengan perang. Sikap ini muncul berkali-kali dengan terus mengkritik pemerintah yang menandatangani "perjanjian Linggarjati dan Renville" dengan Belanda. Ini adalah contoh perjuangan bersenjata yang di lakukan oleh umat Islam pada masa revolusi.

\section{b. Perjuangan Diplomasi}

Selama hampir lima tahun setelah proklamasi kemerdekaan, Indonesia memasuki masa-masa revolusi (1945-1950), menyusul kesalahan Jepang, oleh tentara Sekutu, Belanda bermaksud untuk kembali ke pulau Nusantara. Selama periode ini, tidak ada hambatan serius yang menghalangi hubungan politik antara kelompok Islam dengan kelompok nasionalis. Perdebatan-perdebatan diantara mereka mengenai corak hubungan antara Islam dan negara seperti di jelaskan sebelumnya sebelum kemerdekaan dihentikan. Mereka, paling tidak untuk sementara, bersedia melupakan perbedaanperbedaan idiologis diantara mereka. Dan tidak diragukan lagi, pada masa itu, para pendiri republik merasa bahwa mereka harus mengerahkan seluruh tenaga dan 
Dinamika Perjuangan Kaum Muslim.......Lalu Murdi dan Muhammad Shulhan Hadi

kemampuan untuk mempertahankan republik Indonesia yang beru berdiri dan mencegah Belanda untuk kembali berkuasa (Bahtiar Effendi, 1998: 92).

Karena dasar itulah, pada tenggal 18 Agustus, sehari setelah proklamasi kemerdekaan Indonesia dikumandangkan, dalam pembahasan dasar negara yang akan di ambil dari Piagam Jakarta, dank arena didorong oleh desakan Hatta, kelompok Islam (diwakili Ki Bagus Hadikusumo, Wahid Hasjim, Kasman Singodimejo, dan Teuku Muhammad Hasan), berseakat untuk menghapus kata "Kewajiban menjalankan syariat Islam bagi pemeluk-pemeluknya (Bahtiar Effendi. 1998: 90). Hal ini memang di luar dugaan karena sebelum kemerdekaan terjadi perdebatan idiologis yang cukup inten.

Namun ada beberapa dugaan mengenai mengapa para pemimpin kelompok Islam bisa segera menerima penghapusan salah satu bait pertama dalam Piagam Jakarta tersebut. Pertama, dimasukannya kata-kata "Yang Maha Esa" dapat dilihat sebagai langkah simbolik untuk menunjukkan kehadiran unsure monotetik Islam dalam idiologi negara. Kedua, situasi yang berlangsung menyusul diproklamasikannya kemerdekaan mengharuskan para pendiri republik ini untuk bersatu menghadapi masalah-masalah lain (Bahtiar Effendi, 1998: 91).

Berdasarkan alasan ini, mengenai perdebatan idiologi ini, walaupun mereka tetap memperjuangkan asas Islam, tetap berlangsung secara konstitusional, meski sebagian organisasi keislaman seperti DI/TII memperjuangkan idiologi Islam dengan cara ekstrim yaitu memisahkan diri dari NKRI. Bagi mereka yang memperjuangkan Islam sebagai dasar negara secara konstitusional, misalnya dengan melihat pada adanya celah kemungkinan perubahan UUD 1945. Mereka berpegang pada pasal 7 UUD 1945 yang menyatakan bahwa UUD dapat diubah oleh 2/3 dari anggota DPR/MPR (Turmudi E., Sihbudi Riza, 2005: 229).

Berdasarkan penjelasan di atas, mengenai perdebatan idiologi ini tidak akan kita bahas. Dan yang perlu menjadi perhatian adalah corak diplomasi dalam rangka perjuangan mempertahankan kemerdekaan ini. Dalam rangka ini, pemimpin nasional dalam bingkai kesatuan (baik tokoh nasional dan agama) mengedepankan pencapaian dejure kemerdekaan Indonesia dari pemerintahan Belanda. Kerena itu tokoh islam juga mengikuti jalur ini sebagai jalan untuk mempertahankan kemerdekaan tersebut. Terdapat dua bentuk diplomasi yang dilancarkan oleh tokoh-tokoh Islam dan nasional 
Dinamika Perjuangan Kaum Muslim.......Lalu Murdi dan Muhammad Shulhan Hadi

yaitu diplomasi dengan pemerintahan belanda yang notabenenya ingin menguasai kembali republik Indonesia, selanjutnya dengan mencari dukungan dari luar negeri.

\section{1) Diplomasi dengan Belanda}

Setelah sistem presidensial diganti dengan kabinet ministrial dan Sutan Sjahrir di tunjuk sebagai perdana mentri pertama. Pemerintah baru ini (Kabinet Sjahrir mengadakan kontak diplomatik dengan pihak belanda dan Inggris. Kebijakan pemerintah yang pada saat itu dengan jalan diplomatik di amini juga oleh kalangan tokoh Islam.

Salah satu contoh ketika terjadi perundingan yang diselenggarakan di atas kapal angkatan perang milik Angkatan Laut Amerika Serikat, USS Renville di buka pada tanggal 8 Desember 1947, yang di kenal dengan perjanjian Renvillle, salah satu tokoh islam H.A. Salim ikut sebagai anggota delegasi (Poesponegoro, Notosusanto, 1993: 141). Begitu juga dalam hubungan diplomasi dengan negara-negara Barat dan negaranegara di Asia lainnya seperti India tokoh-tokoh islam ikut serta di dalamnya.

\section{2) Mencari dukungan dunia Islam}

Setelah proklamasi kemerdekaan Indonesia, para tokoh-tokoh Islam yang memang sebelumnya telah berhubungan baik dengan tokoh-tokoh yang ada di negaranegara Islam, dan notabenenya Indonesia merupakan negara mayoritas Islam terbesar di dunia menyebabkan negara-negara Islam yang ada di Timur Tengah sangat merespon kemerdekaan Indonesia tersebut, karena itulah negara Islamlah yang mengakui kemerdekaan Islam secara de facto merdeka.

Republik Arab Mesir sebagai contohnya merupakan negara pertama yang mengakui kemerdekaan dan kedaulatan RI pada tanggal 18 November 1946. Bersamasama dengan India dan Pakistan serta negara-negara Liga Arab, telah turut aktif mendukung perjuangan kemerdekaan RI di kancah diplomatik internasional yang saat itu masih dalam ancaman penjajah Belanda.

Peran penting Mesir dalam membantu Indonesia mempertahankan kemerdekaannya tampak jelas dari kunjungan Muhammad Abdul MUn'im, Konsul Jendral Mesir di Bombay (sekarang Mumbay, India) yang datang ke Yogyakarta (Ibukota RI saat itu) pada tanggal 13-16 Maret 1947. Menurut Anis Rasyid Baswedan, Muhammad Abdul Mun'im melakukan kunjungan ke Indonesia untuk mewakili 
Dinamika Perjuangan Kaum Muslim.......Lalu Murdi dan Muhammad Shulhan Hadi

negerinya dan membawa pesan dari Liga Arab yang mendukung kemerdekaan Indonesia.

Pada tanggal 15 Maret 1947, bertepatan dengan ulang tahun kemerdekaan Mesir yang ke-23, Beliau menghadap Presiden Soekerno untuk menyampaikan pesan-pesan dari Liga Arab. Pesan tersebut merupakan hasil kesepakatan sidang Dewan Liga Arab yang di selenggarakan pada tanggal 18 November 1946 yang menganjurkan seluruh anggota Liga Arab mengakui kedaulatan Republik Indonesia berdasarkan ikatan keagamaan, persaudaraan, serta kekeluargaan.

Pencarian dukungan ke negara-negara Islam ini tidak lepas dari peran H. Agus Salim yang pada waktu itu menjabat sebagai Wakil Mentri Luar Negeri mengunjungi mesir untuk mendapatkan pengakuan dunia sejak proklamasi kemerdekaan. Bukan hanya itu Agus Salim mendapat dukungan mesir untuk menjalin persahabatan yang ditandatangani oleh H. Agus Salim dari pihak RI, dan dari pihak Mesir diwakili oleh Mahmoud Fahmi Nakrazy, Perdana Mentri merangkap Mentri Luar Negeri Mesir. Dengan demikian, Republik Arab Mesir, menjadi Negara pertama yang dengan resmi mengakui kemerdekaan dan kedudukan RI baik secara de jure maupun de facto. Ini adalah salah satu contoh diplomasi ke negara-negara Islam yang di lakukan tokoh-tokoh Islam di Indonesia.

Dukungan dari negara-negera anggota Liga Arab, khususnya Mesir, terhadap kemerdekaan dan kedaulatan Indonesia atas dasar ikatan keagamaan (islam), persaudaraan, dan kekeluargaan merupakan bagian penting dan faktor utama dalam diplomasi revolusi bangsa Indonesia di masa-masa awal kemerdekaan. Adanya dukungan resmi dari Liga Arab dan kunjungan Konsul Jendral Mesir merupakan peristiwa yang sangat penting dan bersejarah bagi Indonesia, karena untuk pertama kalinya RI sebagai Negara merdeka dan berdaulat menerima kunjungan diplomatic resmi dari Republik Arab Mesir yang membawa pesan dari organisasi internasional Liga Arab.

\section{Kesimpulan}

Secara sederhana, pergerakan untuk mendapatkan kemerdekaan umat Islam Indonesia dapat kita lihat beberapa ciri yang menonjol. Pengklasifikasian ini memang tidak kaku, 
melainkan dinamis, beberapa klasifikasi pergerakan tersebut yaitu, pertama pergerakan reformasi (reform movement), yang ditandai oleh pergerakan umat islam secara damai, namun bertujuan untuk mendapatkan kemerdekaan, dalam hal ini organisasi Islam berusaha untuk mendapatkan kemerdekaan Indonesia dengan jalan konstitusional, dan menunggu tempat yang tepat untuk mendapatkan kemerdekaan di kemudian hari seperti yang di janjikan oleh Jepang. Kedua, pergerakan revolusioner (revolusionary movement) bertujuan untuk mengubah status Indonesia secara langsung dari negara terjajah menjadi negara yang merdeka, dalam hal ini setelah kemerdekaan di kumandangkan para tokoh agama dan nasionalis tidak memberikan lagi kembalinya penguasaan Belanda atas Indonesia dengan jalan diplomasi dan lain-lain. Ketiga, dan terkait juga dengan kedua pergerakan di atas adalah pergerakan perlawanan. Jika perlawanan secara damai melalui jalan yang konstitusional maka jalan inilah yang di tempuh para tokoh Islam dan nasionalis pada umumnya untuk mengusir penjajahan Belanda yang ingin menerapkan status quo-nya.

Perjuangan kemerdekaan oleh umat Islam, walaupun bisa di katakan agama sebagai salah satu faktor perekat persatuan, namun mereka juga memiliki tujuan kemerdekaan yang mungin berbeda. Sehingga corak perjuangan yang mereka jalankan juga berbeda pula. pada saat Jepang menguasi Indonesia, terdapat beberapa corak dari perjuangan umat Islam yaitu, pertama, perjuangan secara politis. Dalam hal ini organisasi-organisasi islam dan tokoh-tokoh Islam berusaha untuk mendapatkan kemerdekaan tersebutt dengan jalan konstitusi dan organisasi yang di legalkan oleh belanda, seperti MIAI yang diganti dengan Masyumi, organisasi sosial keagamaan seperti muhammadiyah, NU, Persis dan lain sebagainya. Sementara itu dalam lembaga persiapan kemerdekaan mereka ikut sebagai anggota BPUPKI dan merumuskan dasar Negara Indonesia merdeka. Kedua, perjuangan idiologi negara. Dalam hal ini kaum muslim memperjuangkan dasar negara adalah syariat Islam, dan mereka tidak berhadapan dengan pihak Jepang melainkan kelompok nasional. Perbedaan antara mereka berkisar pada adanya pemisahan agama dari negera yang di perjuangkan oleh kelompok nasional, sebaliknya kelompok islam memperjuangkan Islam sebagai dasar negara. Ketiga, perlawanan dengan teguran, misalnya tindakan Jepang memberlakukan 
Dinamika Perjuangan Kaum Muslim.......Lalu Murdi dan Muhammad Shulhan Hadi

tradisi seikere tidak hanya ditentang kalangan NU, tetapi juga tokoh Islam lain. Abdul Karim Amrullah, juga menentang tradisi itu.

\section{Daftar Pustaka}

Alisjahbana S. Takdir. 1988. Revolusi Masyarakat dan Kebudayaan di Indonesia. Jakarta: Dian Rakyat.

Damsar. 2010. Pengantar Sosiologi Politik. Jakarta: Kencana.

Dault Adhyaksa. 2005. Islam dan Nasionalisme: Reposisi Wacana Universal Dalam Konteks Nasional. Jakarta: Pustaka Al-Kautsar.

Effendi Bahtiar. 1998. Islam dan Negara: Transformasi Pemikiran dan Praktik Politik Islam di Indonesia. Jakarta: Paramadina.

Haedari Amin. 2004. Masa Depan Pesantren: Dalam Tantangan Modernitas dan Tantangan Kompleksitas Global. Jakarta: IRD Press.

Kahmad Dadang. 2006. Sosiologi Agama. Bandung: Remaja Rosdakarya.

Mukhsin Jamil dkk. 2007. Nalar Islam Nusantara: Studi Islam ala Muhammadiyah, AlIrsyad, Persis dan NU. Jakarta: Depag RI, Direktorat Jendral Pendidikan Islam, Direktorat Pendidikan Tinggi Islam.

Nizar Samsul. 2011. Sejarah Pendidikan Islam: Mencari Jejak Sejarah Pendidikan Era Rasulullah Sampai Indonesia. Jakarta: Kencana.

Poesponegoro M. D, Notosusanto N. 1993. Sejarah Nasional Indonesia VI. Jakarta: Depdiknas Balai Pustaka.

Sartono Kartodirdjo. 1990. Pengantar Sejarah Indonesia Baru: Sejarah Pergerakan Nasional Dari Kolonialisme Sampai Nasionalisme. Jakarta: Gramedia.

Soedjatmoko, dkk. 1995. Historiografi Indonesia: Sebuah Pengantar. Jakarta: Gramedia Pustaka Utama.

Suhelmi Ahmad. 2002. Polemik Negara Islam: Soekarno Versus Natsir. Jakarta: Teraju. Supardan Dadang. 2011. Pengantar Ilmu Sosial: Sebuah Kajian Pendekatan Struktural. Jakarta: Bumi Aksara.

Thohir Ajid. 2009. Perkembangan Peradaban di Kawasan Dunia Islam. Jakarta: Rajawali Press.

Turmudi E, Sihbudi R. ed. 2005: Islam dan Radikalisme di Indonesia. Jakarta: LIPI Press.

\section{Internet:}

Adabiydarban dalam http://adabydarban.blogspot.com/1212//04/peranan-islam-dalamperjuangan.html

http://ajisetiawan1.blogspot.com/2011/11/nu-dalam-persiapan-dan-setelah.html

http://facebook.com/notes/nu-campus/komitmen-nahdlatul-ulama-nu-terhadapperjuangan-bangsa-indonesia/

http://muhammadibrahimhamdanii.wordpress.com/1212/02/21/memori-historisindonesia-mesir-pengakuan-kedaulatan-republik-indonesia-oleh- 